\title{
Martin Luther se leer oor die doop volgens sy De Captivitate Babylonica Ecclesiae praeludium van 1520
}

A D Pont

Emeritus-professor: Departement Kerkgeskiedenis en Kerkreg (Afd A)

Universiteit van Pretoria

\begin{abstract}
Martin Luther's doctrine of baptism according to the De captivitate Babylonica ecclesiae praeludium of 1520

In this study Luther's doctrine on baptism, as found in his 'De captivitate Babylonica ecclesiae praeludium' of 1520 is studied. This is not an exhaustive study of Luther's complete doctrine on baptism. It only explores his views on this sacrament which, according to his thesis, is held in captivity by the Roman doctrine on baptism. It is found that Luther, in this work, shifts the existing emphasis on the sacramental elements to the primacy of the Word and faith in that redemptive Word.
\end{abstract}

Denn er hat uns die Worte gegeben: das ist der Brief. Und neben den Worte die Taufe: das ist das Siegel. Dass so der Glaube, welcher das Wort fasst, durch das Zeichen und Siegel gestärkt werde. Aber da siehest du noch kein Menschenwerk. Denn die Taufe ist nicht mein, sondern Gottes Werk.

(Hemelvaartspreek: Mark 16:14 op 14 Mei 1523. WA 12.561.)

\section{INLEIDING}

Op 18 Februarie 1546 is Martin Luther in Eisleben oorlede. Dit is nou al 450 jaar gelede en nog steeds is die teologie en die invloed van hierdie begenadigde dienskneg van ons Here Jesus Christus 'n lewende werklikheid. Hoewel ons in die tradisie van Calvyn, die jonger tydgenoot van Luther staan, bly dit waar dat die gemeenskaplike in die teologie van Luther en Calvyn dalk meer is as die verskille. Luther wat met sy herontdekking van die Bybel as die Woord van God (Pinomaa 1964:125v) en die leer

* Referaat gelewer op 19 November 1996 tydens die jaarlikse kongres van die Kerkhistoriese Genootskap van die Nederduitsch Hervormde Kerk van Afrika, op die kampus van die Universiteit van Pretoria. 
van die regverdiging van die sondaar deur die geloof alleen, 'n enorme bres geslaan het in die Rooms-Katolieke monnikevroomheid en teologie, het die begin gevorm van die magtige kerkhervormende beweging van die $16 \mathrm{e}$ eeu.

Calvyn, wat die groot Protestantse teoloog en leier is as die Rooms-Katolieke Kerk teenhervorming vaart begin kry, het sy hele teologie ook op die basis van dieselfde leerstuk gebou. Ons kan sê dat ons vandag ook erfgename van Luther is, al formuleer ons daardie teologiese en geestelike erfenis soos Calvyn dit aan ons geleer het.

As ons verder dink aan die bekende woord van Calvyn oor Luther, soos hy dit op 25 November 1544 aan Bullinger skrywe, dan betaam dit ons seker om aan die einde van hierdie herdenkingsjaar ook 'n oomblik by Luther stil te staan. Calvyn het destyds geskrywe (OC 11,774-5):

Bedink tog ... hoe 'n groot figuur Luther ongetwyfeld is, deur watter buitengewone geestelike gawes hy hom onderskei, hoe dapper en onwrikbaar, hoe bekwaam, geleerd en hardwerkend hy steeds gearbei het aan die verwoesting van die ryk van die antichris en aan die uitbreiding van die leer van die verlossing ....

Dan noem Calvyn Luther ' $\mathrm{n}$ voortreflike dienskneg van God en maan Bullinger dat hy hier te make het '... met 'n eersteling onder die diensknegte van God aan wie ons almal baie verskuldig is'.

Dit is gepas om by ' $n$ herdenking van Luther en sy werk iets te sê oor Luther se leer van die doop. Dit juis omdat by die doop die begin- en uitgangspunte van die Rooms-Katolieke Kerk, Middeleeuse monnike- of verdienstevroomheid so duidelik sigbaar word. Wanneer Luther in 1517 in sy 95 stellings die Rooms-Katolieke Kerk se aflaat- en boetepraktyk aanval, dan sê hy in stelling 62: Verus thesaurus ecclesie est sacrosanctum evangelium glorie en gratie dei (Clemen 1966:1.7). Met dié proklamering van die primaat van die magtige Woord van God was dit vanselfsprekend dat Luther ook aandag moes gee aan die sakramente wat destyds die sentrum en byna die somtotaal van die Rooms-Katolieke Kerk se godsdiensoefening was. Reeds in 1519 praat Luther oor die doop (Clemen 1966: 1.185-195) en die mis (Clemen 1966: 1.196212) in sy prediking. Die eerste aanduiding van 'n Skrif-bepaalde sakramentsleer asook grondige kritiek teen die heersende opvattings en praktyke spreek Luther uit in sy Ein sermon von dem Neuen Testament, d.i. von der heiligen Messe van 1520 (Clemen 1966:1.299-322).

Die groot lyne wat Luther hier getrek het, het hy verder uitgewerk in sy omvangryke geskrif van 1520 De captivitate Babylonica ecclesiae praeludium. Hier is sy tema dat die sakramente van die doop, die boete en die nagmaal in gevangenskap gehou 
word deur die Rooms-Katolieke Kerk se curie en dat die hele kerk sodoende van sy vryheid beroof is. Hier trek Luther skerp skeidslyne en verwerp die opvattings van die skolastieke Rooms-Katolieke Kerk se sakramentsleer sowel as die kanonieke reg. Hierdie geskrif wat saam met sy twee ander beroemde publikasies van 1520, An den christlichen Adel en die Von der Freiheit eines Christenmenschen, sy teologiese posisie baie duidelik weergee, het volgens Erasmus enige poging om die geskille tussen Luther en die pous te besleg, finaal gekelder (Allen 1922:122-135). Dit is duidelik dat Luther met dié geskrifte, vir die gevoel van sy tydgenote, nie net verkeerdhede in die RoomsKatolieke Kerk aanwys nie maar baie verder gaan en die kerkwees van die RoomsKatolieke Kerk bevraagteken. Nie net dit nie, maar in sy De captivitate Babylonica lê Luther die grondslae vir 'n totaal-nuwe Bybelse sakramentsleer.

\section{ENKELE OPMERKINGS OOR DIE ROOMS-KATOLIEKE KERK SE SAK- RAMENTSLEER EN DIE DOOP}

As Luther getipeer word as 'n teoloog van die Woord van God, dan word daarmee al aangedui dat hy die Rooms-Katolieke Kerk se sakramentsleer nié sal kan aanvaar nie. Daarom is dit nodig om net enkele opmerkings hieroor te maak. Om mee te begin kan gestel word dat die Rooms-Katolieke Kerk se leer oor die sakramente 'n betreklike laat ontwikkeling was. In die vroeë kerk is al die aandag opgeëis deur die groot vrae rondom die leer van die Drie-eenheid en die menswording van Jesus Christus. Die vroeë konsilies en sinodes het in die omstandighede nie aandag aan 'n leer oor die sakramente gegee nie. Die sakramente is verstaan as elemente van die erediens wat gebruik en gevier word en nie, in die eerste plek, as waarhede wat uitgele moes word nie. Daarom is daar nie juis daarop ingegaan nie.

Die begrip sakrament wat in die Latynse kerk gebruik word, is in sy oorspronklike betekenis 'n verwysing na 'n soldaat se eed van lojaliteit en trou. In die Latynse kerk is die woord gebruik as 'n vertaling van die Griekse musterion. In daardie sin het dit verwys na elemente sowel in die erediens as in die lewe van die gelowiges. Augustinus omskrywe 'n sakrament as die sigbare vorm van die onsigbare genade en sluit daarby die belydenis en die gebed in. Hierdie breë betekenis bly gangbaar in die Middeleeue totdat Petrus Lombardus in sy Sententiae (4.1.2) sewe kerklike, liturgiese handelinge as sakramente aandui. Sy sewe sakramente word deur Thomas van Aquino en die konsilie van Firenze 1439 en Trente 1545-1563 so aanvaar en vasgestel.

Die sakramente word dan verstaan as die manier waarop die genade van God aan die mens gegee word. So gesien is die sakramente instrumente terwyl die genade 'n selfstandige wese of substantia het wat deur middel van die sakrament aan die gelowige gee word. Dit is dan die gratia infusa. Die bedoeling van die sakramente is om die 
hele lewe van die gelowige met die heil van God te vul. As sodanig is die sakramente 'n analogie van die menswording van Jesus Christus, die Seun van God, want hier word 'n geestelike werklikheid in 'n materiële vorm gegiet tot heil van die mens. So is die sakrament ' $n$ voortsetting van die menswording van God aangesien die kerk buitendien die mistieke liggaam van Christus is waar die gelowiges in Christus opgeneem word en deur Hom ook met mekaar verenig word. So word die kerk wat die sakramente uitdeel, ' $n$ omvattende heilsinstituut wat die genade van God beheer en uitdeel want die kerk staan tussen God en mens en kanaliseer die heil wat van God uitgaan na die mens toe.

Aanvanklik word die twee elemente van die sakrament nog onderskei naamlik die materiële element, die materia of res en die formele element, die forma of verba. Dan is dit nog aanvaar dat die sakrament 'n heenwysende karakter het en dat dit 'n ondersteuning van die geloof is. Dit word selfs aanvaar dat die prediking die inhoud van die sakrament bepaal. Maar geleidelik wen die opvatting veld dat die sakrament wat wettig, dit wil sê volgens die kerklike reël bedien word, uit eie krag dit meedeel waarvan dit 'n teken is. So stel die Vierde Lateraanse Konsilie vas in 1215: 'sacramentum vero baptisma ... tam parvulus quam adultis ... proficit ad salutem' (Alberigo et al 1962: 207-209). Daarmee word 'n gedagte van Augustinus dat die doop net soos die priesterwyding 'n character indelibilis aan die ontvanger toeken, bestendig (Augustinus: De Bapt 1.4.5).

Die Middeleeuse sakramentsleer word die duidelikste deur Thomas van Aquino 1225-1274, die gesaghebbende doctor communis et angelicus, saamgevat. In sy Summa Theologica stel hy dat die sakramente van die nuwe bedeling meer is as 'n teken van genade want die sakramente deel self genade mee (Summa 3.62.1; vgl ook Bernhart 1954:3.622) omdat dit funksioneer soos instrumente van God wat op die siel inwerk (Summa 3.62.4) en daarom deel dit, ook in die doop, 'n character indelibilis mee (Summa 3.63.1). Die leer is deur die Konsilie van Firenze bevestig (Alberigo et al 1962:517) en dan word ook gesê dat die effek van die doop die vergiffenis is van alle sondeskuld sowel die skuld van die erf- as die daadsonde (huius sacramenti effectus est remissio omne culpe originalis et actualis ...) sodat die doop die gedoopte sondeloos maak (Alberigo et al 1962:519).

Dit kom dus daarop neer dat gestel word dat die objektiewe krag van die sakrament op die handeling van God berus (opus operatum), dat die subjektiewe werking berus op die toestemming van die ontvanger (opus operantis) terwyl dit die priester (ministerium) is wat die werk van God kanaliseer. Tog is dit so dat die konsekrasiewoord van die priester die sleutel tot die werking van die sakrament is en juis so word die sakramentsgenade in werklikheid die besit van die kerk (vgl Summa 3.64.8). 
Samevattend kan gese word dat in Luther se dae die doop verstaan is as die eerste sakrament wat aangevul word deur die bieg en sy voltooiing vind by die mis. Die doop vul die sondaar met bonatuurlike $\mathrm{krag}$, want nie alleen word die erfskuld vergewe nie maar word die beeld van God in die mens volledig herstel en kan die gedoopte die ewige lewe beërwe. Hoewel die volledige inlywing van die gelowige in Christus eers by die ontvang van die mis plaasvind, skenk die doop dit reeds in beginsel. Met die leer dat die sondaar by die doop effektief gereinig word van die skuld van die erfsonde is die pad oopgemaak dat die mens self die heil, weliswaar ondersteun deur die sakramentsgenade van die kerk, kan verwerf.

Wat Luther in beginsel verwerp, is die opvatting dat die heilige gebruike en formules 'n outomatiese krag en vermoë sou hê om aan die mens die heil te gee. Luther beoordeel dit as towery wat volledig in teenspraak met die evangelie is. Dit ook omdat hierdie opvatting God aan die mens diensbaar maak, want die konsekrasiewoord van die priester laat die sakramentselement outomaties funksioneer en dwing God om die heil aan die sondaar te gee.

As in berekening gebring word dat die sakramentsisteem een van die belangrikste boustene van die Middeleeuse kerklike kultuur, godsdiens en vroomheid was, is dit duidelik hoe skokkend Luther se totale verwerping van die Rooms-Katolieke Kerk se leer en praktyk moes ingewerk het (Boehmer 1955:265-266).

Wat gebeur het, is dat die Middeleeuse kerk en teologie daarin slaag om die gevaarlike en die onberekenbare van die almagtige God wat volkome anders as die mens is, as't ware te tem. Soos die mens met sy. vernuf en werkvermoë die geweldige en soms gevaarlike krag van 'n rivier kan tem deur 'n dam te bou en dan die water diensbaar te maak aan die mens se behoeftes, so is God se genade ingedam en ingespan deur die kerklike amp. God se genade is geproklameer tot 'besit' van die kerk en die gevolg is dat die priester wat die 'towerspreuk' van die konsekrasiewoord spreek, die genade, die ontferming en die sondevergiffenis van God beheer en aanwend ten behoewe van die heilsoekende sondaar. Daarom word mettergaan die totale diens van die Middeleeuse kerk gekonsentreer op die viering van die sakramente. Die Bybel raak heeltemal op die agtergrond want die pous, die hoof van die kerk en die vicarius Christi het as't ware die Bybel in sy besit en kan hy die gesaghebbende woord spreek ( $\mathrm{vgl}$ in hierdie. verband CCL 1993, Canones 747, 749, 752, 834, 835 en 840).

Luther wat deur die Bybel geleer word wat God se Woord is, dat God nie deur die mens ingeperk kan word nie, het die leer en praktyk van die Middeleeuse kerk as die poging van die mens om God gevange te neem en aan die mens diensbaar te maak, radikaal verwerp. Sy hele dienswerk was daarop gerig om daardie gevangenskap ongedaan te maak en daarom stel hy teenoor die Rooms-Katolieke Kerk se sakramentsteolo- 
gie die boodskap van die ewige, magtige Woord van God wat mens geword het maar waaroor die mens nie kan beskik nie.

\section{LUTHER SE LEER VAN DIE SAKRAMENT}

Luther se opvatting oor die sakrament, om die agtergrond en raamwerk van sy denke 'n oomblik te skets, is ' $n$ onderdeel van sy hele teologie. Daarom moet daarop gelet word dat Luther die lewe van die gelowige sien as 'n lewe van stryd en aanvegting. Die vervulling van God se beloftes in en deur Jesus Christus beteken nog nie dat die gelowige in die wêreld nou losgemaak is van die gehoorsaamheid aan die Wet of volledig bevry is van die sonde nie. Want die sonde, hoewel Christus dit aan die knis oorwin het, behou nog die oorblyfsels van sy mag tot by die weerkoms van Christus. Hierdie tussentyd, tussen Hemelvaart en Weerkoms, is die tyd van die kerk met sy verkondiging.

Die verkondiging van die evangelie van die regverdiging deur die geloof in Christus skep wel 'n nuwe werklikheid maar dit is nie altyd sigbaar nie want Christus is die lydende Messias wie se oorwinning nog moet blyk. Daarom wys die kerk altyd na die toekoms en die voleinding wat daar sal plaasvind. Die kerk is dus kerk-van-die-geloof, kerk-van-die-geregtigheid wat egter nie nou al volledig sigbaar is nie. Daarom is die kerk kerk-van-die-Woord en van die sakrament. Dit is die twee kanale waardeur Christus aan sy kerk lewe en voeding gee.

Die sakramente is vir Luther handelinge, gebruike maar veral tekens wat Christus ingestel het om daarmee sy werklike teenwoordigheid by sy gemeente uit te druk (WA 6.572.10-15). Dit is van belang dat die sakrament verstaan en gebruik sal word as ' $n$ gawe van Christus en nié as 'n heilige handeling waaroor die kerk beskik nie. Luther het dit so omskrywe (WA 30/1. 230.10-14; Der Grosse Katechismus 1529):

Die hoogste kuns is om te weet dat ons sakramente nie op ons menslike waardigheid berus nie. Want ons laat ons nie doop as mense wat waardig en heilig is nie, ons kom nie na die bieg asof ons rein en sonder sonde is nie. Inteendeel (ons kom) soos arm, ellendige mense terwyl ons onwaardig is.

Die lyn waarlangs Luther oor die sakrament dink is die hele saak van die verlossing van die mens uit die sonde (WA 40/2. 442.33-443.16; Ennaratio Psalmi LI, 1532). In die regverdiging van die sondaar deur die geloof alleen, is dit God alleen wat handelend besig is. Dit is God wat die geloof gee en so die sondaarmens laat deel in die verlossing uit die sonde wat Jesus Christus is. Dit is deur die Woord, meer spesifiek deur 
die verkondiging van die Woord, wat God die geloof in die mens wek en bou en so word dit duidelik hoe God sy beloftes aan Woord en sakrament verbind het. Maar ook in die sakrament bly God die handelende en is alle menslike werk rondom die regverdiging deur die geloof en die verlossing van die mens onnodig en selfs nutteloos (Kantzenbach 1965:211). Dit beteken dat Luther die bevoegdheid van die priester, om deur middel van die konsekrasiewoord, die gratia infusa effektief aan die lidmaat wat die sakrament ontvang, mee te deel as 'n nie-Bybelse stelling verwerp.

In sy De captivitate Babylonica stel Luther nog dat daar net drie werklike sakramente is, naamlik die doop, die boete en die nagmaal. Maar ook hierdie drie is '... deur die Rooms-Katolieke Kerk se curie in 'n ellendige gevangenskap gevoer ....' Dan sê hy '... as ek volgens die gewoonte van die Skrif (usu scripturae) wil praat, dan sou ek maar één sakrament oorhou en drie sakramentele tekens (WA 6.501.20f). Daar één sakrament het Luther in Februarie aangedui as die '...sacrae literae ... quod est ipse Christus dominus' (WA 6.86.7. Dit is stelling 18 in sy Disputatio de fide infusa en acquisita). Diế oorwig wat Luther aan die Woord en belofte van God gee, het hy baie duidelik in sy leer van die doop deurgetrek.

\section{LUTHER SE DOOPBESKOUING IN DIE DE CAPTIVITATE BABYLONICA}

Luther begin met die argument dat die doop nog '... ongedeerd en nie besoedel deur die instellings van mense ...' (WA 6.526.37v) bewaar gebly het in die Rooms-Katolieke Kerk. So het God se bedoeling met die sakrament bly voortbestaan dat $\mathrm{Hy}$, deur die doop, kinders in sy kerk wil inwy en '... deur 'n baie eenvoudige geloof deur die waarheid van sy Woord wil laat heilig' (WA 6.527.7).

Die instelling van die doop en die betekenis daarvan berus vir Luther enersyds op die doopbevel van Matteus 28:19-20 en andersyds op die belofte in Markus 16. 'Wie tot geloof gekom het en gedoop is, sal gered word; wie nie glo nie, sal veroordeel word' (WA 5.527.39). Luther se argument by die doop én die ander sakramente is dat die gelowige deur die geloof in Jesus Christus alleen geregverdig is en dat die sakrament ' $n$ bevestiging is van die belofte. Daarmee verwerp hy die Rooms-Katolieke Kerk se opvatting dat die elemente van die sakramente iets in of aan die mens kan bewerk.

Dit word duidelik dat Luther se opvatting oor die beloftes van God sentraal staan in sy doopbeskouing. Daarom sê hy dat die sakrament van die prediking onderskei word in dié sin dat by die sakrament dit gaan om die belofte saam met die teken. Hy sê hieroor (WA 6.518.13v): 
Soos in die doop waar (God) aan die woorde van belofte die teken van die onderdompeling in water verbind het. Hierdeur verstaan ons dan dat in elke belofte twee dinge aan ons gegee word: die Woord en die teken sodat ons begryp dat die Woord die testament is en die teken die sakrament is, soos in die nagmaal waar die Woord van Christus die testament is en die brood en wyn die sakrament. En soos daar 'n groter krag in die Woord as in die teken lê, net so is, vergelykenderwys, 'n groter krag in die testament as in die sakrament. Dit omdat die mens die Woord of testament kan hê sonder die teken of sakrament.

Hier moet daarop gewys word dat Luther aan die woord testamentum 'n besondere betekenis gee want dit is vir hom die belangrike in die hele gebruik. Hy gebruik die woord testamentum na aanleiding van die Latynse vertaling van die instellingswoorde van Christus by die laaste maaltyd wat Christus met sy dissipels gevier het. Testamentum is dan Christus se nalatenskap aan sy dissipels en nie teken van die diatheke of verbond nie. Luther stel dat Christus se nalatenskap die vergiffenis van die sonde op grond van die genadegawe van die geloof is. So gesien, wil Luther dit beklemtoon dat dit in die sakrament om 'n genadegeskenk gaan wat elke menslike verdienste of goeie werk uitskakel.

Hoewel Luther se uitleg eksegeties miskien aanvegbaar kan wees, is die saak wat hy stel bo verdenking want soos hy aandui, maak die kinderdoop dit juis onmoontlik om van die dopeling goeie werke te verwag op grond waarvan hy geregtig sou wees op die ingegote genade, soos die Rooms-Katolieke Kerk wel ten opsigte van die mis vereis (vgl WA 6.526.36v).

In ieder geval, Luther se argument is dat die Woord by die teken kom om sodoende die gebeure tot sakrament te mák. Dit dan in navolging van Augustinus se bekende uitspraak: 'Accedat verbum ad elementum et fit sacramentum.' Die uiterlike elemente dra dus nie die gewig nie. Veel eerder moet die gelowiges op die Woord van God let wat aan die sigbare, uiterlike teken inhoud en betekenis gee. Die Woord by die sakrament bevat die naam van God en op grond daarvan sê Luther in 1529 in' sy Groot Kategismus (Clemen 1959:4, 82):

Waar God se Naam is, daar moet ook redding en lewe wees sodat die doopwater met reg 'n Goddelike, reddende, vrugbare en genaderyke water genoem mag word. Want deur die Woord kry die doop die krag om 'n bad van die wedergeboorte (bad der widdergeburt = loutrou paligenesias) te wees soos Paulus dit in sy brief aan Titus (3.5) noem. 
Net soos in sy Ein Sermon von dem Sakrament der Taufe van 1519 (WA 2.731.18 v) lê Luther se verstaan van die doop ingebed in sy herderlike sorg oor die gelowiges. Die beloftes van die doop, so betoog hy, is veral bedoel vir diegene wat in die wêreld blootgestel is aan versoekings en dikwels sonder hoop of uitsig lewe. In dié omstandighede gesien, is die doop vir hom van eksistensiële betekenis en daarom sê hy (WA 6.529.11v):

$\mathrm{U}$ sien hoe ryk 'n Christusgelowige of gedoopte mens is wat, selfs wanneer hy wil, die heil ook nie deur groot sondes kan verloor nie, tensy hy nie meer glo nie. Want geen sonde kan hom veroordeel nie, slegs deur ongeloof kan hy die heil verloor ... want God kan Homself nie verloën nie, indien u Hom bely en gelowig aan sy beloftes vashou.

So gesien, bepaal die doop die hele lewe van die gelowige en die troos van die doop lê daarin dat die doop geheel en al God se werk is. Daarom sê Luther dat die doop wat weliswaar deur 'n mens bedien word, tog so verstaan moet word dat dit Christus, ja God self is wat met sy hand doop (WA 6.530.20v). Die sakramente is immers gegee om die gelowige in sy geloof te versterk en sy vertroue op te bou.

Hoewel Luther dit aan die een kant beklemtoon dat God self in die doop handelend optree, verwerp hy die Rooms-Katolieke Kerk se opvatting waarvolgens die priester as instrument met sy konsekrasiewoord effektief die genade kan meedeel. Daarom leer hy met nadruk dat alleen die geloof wat gerig word deur die Woord en die belofte die sondevergiffenis meedeel. Daardie geloof is egter rie 'n menslike prestasie nie (WA 57.232.27). Daarom is die uiterlike teken vir Luther nie so belangrik nie want dit gaan geheel en al om die betekende saak (WA 6.533.34v). In hierdie verband maak Luther die pragtige stelling (WA $6.530 .20 \mathrm{v}$ ):

Die mens immers doop en tog doop hy nie; hy doop insover hy die werk volbring wanneer hy die dopeling onderdompel; hy doop nié insover hy by daardie werk nie op eie gesag besig is nie maar in die plek van God staan. Daarom moet ons die doop uit die hande van 'n mens nie op 'n ander manier ontvang asof Christus self, ja God self met sy eie hande ons doop nie. Want die doop, hoewel ons dit uit die hand van 'n mens ontvang, is nie van 'n mens nie maar van Christus en van God. 
Daarom kan die doop ook nooit 'n menslike prestasie wees wat die mens aan God aanbied nie.

Die teken van die sakrament van die doop is die indompeling in die water, want betoog Luther, baptizo in Grieks is gelyk aan mergo in Latyn. Baptisma is dus mersio, die indompeling in die water. Hierdie indompeling moet dus afbeeld wat die inhoud van die Woord van belofte is, dit moet afbeeld wat die sakrament werklik beteken (WA 6.531.37v). Om die inhoudelike betekenis van die doop te illustreer sien Luther die doopgebeure as ' $n$ analogie van die sterwe en opstanding van Jesus Christus. Daarvoor beroep hy hom op Romeine 6.4: 'Deur die doop is ons immers saam met Hom in sy dood begrawe, sodat, soos Christus deur die heerlike magsdaad van die Vader uit die dood opgewek is, ons ook so 'n nuwe lewe kan lei.' Want betoog hy, '... die geloof is mos die onderdompeling van die ou mens en die opstaan (uit die sonde) van die nuwe mens' (WA 6.532.30v). Ook hier lê vir Luther die klem op die geloof want na sy mening kan die mens ook sonder die sakrament deur die geloof geregverdig word (WA 6.533.39).

In hierdie verband wys Luther die beskrywing van die doop as ' $n$ afwassing van die sonde af omdat dit nie duidelik genoeg weergee dat die doop die simbool van die sterwe en weeropstaan is nie (WA 6.534.35). Die doop verwys vir Luther na die werklike regverdiging van die mens. Daarom kan Luther ook rondom die doop praat van 'n nuwe skepping, 'n nuwe en ook 'n geestelike geboorte waarop die doop dui. Dit verwys alles vir hom na God se groot daad, waar Hy Hom oor die sondaar ontferm. Tog beteken die doop nie 'n volledige verlossing uit die sonde nie, maar slegs dat die gelowige begin om, deur sy vertroue op God se beloftes en sy gehoorsaamheid aan God, om die sonde af te sterwe. In hierdie lewe kom die mens egter nooit tot sondeloosheid nie want 'n res van die sonde bly steeds die sondaar kniehalter.

Op grond hiervan ontwikkel Luther die argument dat die doop baie meer is as ' $\mathrm{n}$ kortstondige handeling wat aan die begin van die mens se lewe plaasvind. Hoewel die handeling van die bediening eenmalig is, duur die handeling van die betekende saak lewenslank. Solank die gelowige lewe, sterf hy en staan hy op. Daarom is vir Luther die betekenis van die doop dat die mens sterf én lewe en daarom word die doop ook nooit ongeldig nie, al sou die gedoopte gelowige daaraan twyfel. In dié verband sê Luther (WA 6.535.22v):

U begryp dus dat wat ons in hierdie lewe doen in sover dit van krag is om die vlees te dood en die gees lewend te maak (ad mortificationem carnis [et] vivificationem spiritus) tot die doop behoort .... Ons hele 
lewe moet ons doop wees. Dit moet ('n lewe) wees wat die teken of sakrament van die doop in vervulling laat gaan as ons ... alleen aan die een doop toegewy is, dit wil sê: toegewy aan sterwe en die weer opstaan.

Uiteindelik sal God in die eindtyd sy werk aan die gelowige wat Hy met die doop begin het, voltooi. Daarom kan Luther die doop, wat lewenslank geldig bly, steeds tipeer as gawe en opdrag.

In die De captivitate Babylonica beskrywe Luther die doop as 'n genadegawe van God wat die mens op sy pad van die wieg na die graf teken en begelei. Hoewel by die doop die handeling van God verborge is in die daad en woord van die ampsdraer wat doop, is dit tog God self wat hier werksaam is. God het hier die inisiatief en neem die mens, nog voor hy verstand het, op in sy genadeverbond. So ontvang die mens die krag van die geloof om die sonde af te sterwe en na die eis van die Wet in geregtigheid te lewe. Dit dan, sonder dat God soos by Rome as 't ware gedwing word deur die konsekrasiewoord van die priester, om die elemente van die sakrament te laat funksioneer en so genade mee te deel.

In die doop gee God in sy genade aan die gelowige 'n seën wat sy lewe lank geldig bly. Daarom is die gelowige verplig teenoor God om sy lewe lank daarop te roem dat hy gedoop is (WA 6.354.25).

Samevattend word dit duidelik dat Luther twee belangrike elemente van die Rooms-Katolieke Kerk se doopopvatting verwerp. Die een is dat die doop sowel die erf- as sondeskuld uitwis sodat die gedoopte, nadat hy die sakrament ontvang het, effektief sondeloos is. Daarvandaan hoef die sondaar in sy verdere lewe slegs sy daadsondes uit te boet. Om dit te kan doen is al die ander sakramente beskikbaar. Dit beteken dat die mens reeds in hierdie lewe, as hy gereeld die genademiddels van die kerk gebruik, volkome sondeloos kan word. Dit gebeur byna vanselfsprekend omdat die kerk die heil besit en kan uitdeel. Hier is dus 'n heilsleer waar Jesus Christus slegs indirek die Verlosser is. Dié opvatting word deur Luther as teen-Bybels verwerp. Dié oppervlakkige verstaan van die sonde het Luther in 1521 ook bestry (WA 7.445.18-26: Grund und Ursach aller Artikel D Martin Luther, so durch römische Bulle unrechtlich verdammt sind) as hy stel:

Niemand moet daaraan twyfel nie dat al ons goeie werke, wanneer hulle volgens die oordeel en erns van God beoordeel word, doodsondes is ... Paulus sê in Romeine 3.19: die Skrif sluit ons almal onder die sonde in 
sodat die hele wêreld voor God skuldig is en moet erken dat niemand deur goeie werke geregverdig kan word nie, maar alleen wanneer God Hom oor ons ontferm en uit genade regverdig. Dit is die regte, Christelike leer waardeur ' $n$ mens leer om God te vrees en te vertrou. Op grond hiervan kan 'n mens dan God liefhê en loof omdat hy sy eie vermoë betwyfel en volledig op God se genade vertrou.

Luther se verstaan van die sonde bring mee dat hy die Rooms-Katolieke Kerk se semi-Pelagiaanse mensopvatting nie aanvaar nie. Dit beteken terselfdertyd dat hy die uitgangspunt en basis van die Rooms-Katolieke Kerk se vroomheid en teologie wat daarop gebou is, as on-Bybels moet verwerp.

Die tweede saak rondom die Rooms-Katolieke Kerk se doopopvatting wat skerp deur Luther aangeval word, is die opvatting dat die pous of wel die kerk of die priester wat plaaslik die kerk is, die heil wat God gee 'besit,' en in die sakrament kan uitdeel. Luther stel dit so (WA 6.536.15):

Een ding ... word as opdrag aan ons in hierdie lewe gegee en dit is dat ons ons sal laat doop. Dit beteken dat ons doodgemaak word én lewe deur die geloof in Christus. Alleen hierdie geloof moes ons geleer het en die Opperherder was die een by uitstek wat dit moes gedoen het.

Maar nou, terwyl volledig oor die geloof geswyg word, is die kerk begrawe onder ontelbare wette oor goeie werke en seremonies. So is die krag van die regte verstaan van die doop weggeneem en die geloof in Christus belemmer.

In 'n skerp aanval op die pous en die Rooms-Katolieke Kerk se priesterdom beskuldig Luther die clerus dat hulle die vryheid van die gelowige méér inperk en aan bande lê as wat die Turke dit doen (WA 7.536.25). Luther sê dan (WA 6.537.20): 'Terwyl hulle (= die clerus) wolwe is, wil hulle soos herders voorkom; terwyl hulle Antichriste is, wil hulle soos ware christene geëer word.' So sterk voel Luther oor die manier waarop die Rooms-Katolieke Kerk clerus ingeskuif het tussen God en mens en hulle dan aanmatig om daardie verhouding te bepaal, dat hy stel (WA 6.537.35):

Maar dit alles het die pouslike tirannie reeds baie eeue lank meer as oorvloedig tot vervulling gebring: hulle het die geloof vernietig, die sakramente verduister en die evangelie onderdruk. (Maar meer nog) het 
hulle hulle eie nie net goddelose en heiligskennende maar ook barbaarse en dom wette aan die kerkvolk opgelê en vermenigvuldig.

Luther wys die manier waarop die clerus die sakrament verdraai het deur dit in te voeg in hulle verkeerde verstaan van die verhouding tussen God en mens volledig af. Daarom sê hy (WA 6.538.30): 'Maar dan doen die sakramente wat hulle doen, nié uit eie krag nie, maar uit die krag van die geloof. Sonder die geloof, soos ek gesê het, kan die sakramente heeltemal niks doen nie'.

Hoewel Luther sy skerpste argumente oor die Babiloniese gevangenskap van die kerk nie in sy bespreking van die doop na vore bring nie, is dit tog duidelik dat hy ook die doop wil losmaak van Rooms-Katolieke Kerk se misbruike wat die doop ingeperk het.

\section{ENKELE SLOTOPMERKINGS}

In 'n artikel het S J Botha in 1984 ook Luther se doopleer behandel (Botha 1984:101117) en daarin veral klem gelê op Luther se afgrensing teenoor diegene wat die kinderdoop verwerp het. Dié aspek van Luther se doopleer was in 1520 nog nie ter sake nie en word nie hier behandel nie. Hier is aandag gegee aan die feit dat Luther die swaartepunt van die doop dramaties verskuif het en wel so dat hy wegbeweeg van die betekenis van die elemente van die sakrament na die primaat van die Woord van God en die geloof in daardie verlossende Woord. By Luther was die teologie weer, soos by Augustinus, op grond van die skrif ''n normatiewe van bo-na-onder-bedryf' (Burden 1994:114). Daarin is Luther se teologie, net soos dié van Calvyn, anders as dié van hulle opvolgers (Aalders s a:32-40).

Dit is, 450 jaar na Luther se dood, miskien nie onvanpas om na die lees van Luther se geskrif te vra of die kerk nie dalk wéér in 'n Babiloniese gevangenskap verkeer nie. Veral as in berekening gebring word hoe die kerk in Europa besig is om nie net in invloed nie, maar ook in getalle te krimp. Die groot verskil tussen Luther se leer oor die doop en wat vandag in die kerk van die doop gedink en gesê word, word duidelik as gelet word op 'n woord uit Luther se Groot Kategismus (Clemen 1959:4.88):

So sien mens hoe 'n voortreflike saak die doop is wat ons uit die kake van die duiwel ruk, wat God aan ons as 'n eie geskenk gee, wat die sonde teenwerk en wegneem, wat bowendien die nuwe mens sterk maak en wat altyd werksaam bly totdat ons uit hierdie ellende by die ewige heerlikheid uitkom. 
Wanneer so vanuit die verwysingsraamwerk van die Bybels-Reformatoriese teologie na Luther geluister word, word dit duidelik waarom Calvyn hom getipeer het as '... 'n eersteling onder die diensknegte van God'.

\section{Literatuurverwysings}

Aalders, W s a. De grote ontsporing: Over de verhouding van de Reformatie en de moderne teologie. Den Haag: J N Voorhoeve.

Adam, A 1968. Lehrbuch der Dogmengeschichte. Gütersloh: Gütersloher Verlagshaus Gerd Mohn.

Alberigo, J et al 1962. Conciliorum Oecumenicorum Decreta. Basel: Herder Verlag.

Allen, P S 1922. Opus epistolorum Des. Erasmi Roterodami. Oxonii: UOP. (Hier word verwys na Erasmus se brief aan die teoloë van Leuven, Junie 1521.)

Baum, G, Cunitz E \& Reuss, E (eds) 1863-1900. Ioannis Calvini Opera quae supersunt omnia. Brunsvigae: GA Schwetschke et filium. (Aangehaal as $\mathrm{OC}$ ).

Bernhart, J (Hrsg) 1954. Thomas von Aquino: Summe der Theologie. Stuttgart: Alfred Kröner Verlag.

Boehmer, H 1955. Der junge Luther. Leipzig: Koehler \& Amelang.

Botha, S J 1984. Luther en die sakrament van die doop, in Martin Luther, 1483-1546. Pretoria: Kital.

Clemen, O (Hrsg) 1959 vg. Luthers Werke in Auswahl. Berlin: Walter de Gruyter \& Co.

The Code of canon Law. London: Collins (aangehaal as CCL).

Herman, R 1967. Luthers Theologie. Göttingen: Vandenhoeck \& Ruprecht.

Kantzenbach, F W 1965. Martin Luther und die Anfänge der Reformation. Gütersloh: Gütersloher Verlaghaus Gerd Mohn.

Klug, I s a. Het Katholieke geloof. Heemstede: Uitgeverij de Toorts NV.

Luther, M 1520. De captivitate Babylonica ecclesiae praeludium, in D Martin Luthers Werke. Kritische Gesammtausgabe, BD VI, 484-573. Weimar 1888: Herman Bohlau. (Aangehaal as WA).

Pinomaa, L 1964. Sieg des Glaubens. Göttingen: Vandenhoeck \& Ruprecht. Palmer, P F 1957. Sacraments and Worship. London: Longmans Green \& Co.

Von Loewenich, W 1982. Martin Luther: Den Man und das Werk. München: List Verlag. 